\title{
Teacher Pedagogic Competency and National Examination Result at Elementary School
}

\author{
Putu Eka Suarmika \\ University Abdurachman Saleh Situbondo, Jawa Timur
}

\begin{abstract}
This study aims to determine the relationship of teacher pedagogic competence to the national science exam results in elementary schools in the district Gerokgak. The population in this research is all the sixth grade teachers in gerokgak sub district and the sample in this research is 29 teachers. Instrument in this research using pedagogic competence questionnaire and the value of national examination result of academic year 2016/2017. The research method used is ex post facto while the data analysis using correlation analysis with the help of SPSS 16. Based on data analysis, it is found that the pedagogic competence relationship of teacher to the result of national science test shows the correlation of being with kofesien $r h o=0.47$. While the pedagogical competence of teachers contributes as much as $22.09 \%$ to the national science exam results, and $67,91 \%$ is influenced by other variables not implemented in this study. Pedagogical competence is primarily concerned with the level of understanding of learners, instructional design, and implementation of learning the diagnosis, evaluation of learning, the development of learners has provided significant support in the form of professional pedagogical teaching

Key words : elementary school, national examination. natural science, and teacher pedagogic competency
\end{abstract}

\section{Introduction}

The imperative in recent years about improving student outcomes is also about improving the quality of the teaching workforce. In recent years, however, recruiting and retaining quality teachers has become a challenge among some OECD countries. In addition to the ageing of the teaching workforce, some countries experience high rates of attrition among new teachers and a shortage of quality teachers in high-demand subject areas and disadvantaged schools. There is also concern about attracting high-achieving and motivated candidates into teacher education programmes and the lowering of qualification requirements in the certification and licensing of new teachers [1].

One of vital factors and generally discussed in relation to the quality of education is teacher. A quality teacher is one who has a positive effect on student learning and development through a combination of content mastery, command of a broad set of pedagogic skills, and communications/ interpersonal skills (Hightower et al.,2011) [2]. [3] It is very important because teachers have a crucial factor to determine the quality of education system. Teachers should have the competencies affecting the students' achievements and performances. To meet the demand, teachers should also be able to answer the students' need in their learning. According to the Minister of National Education Regulation No.16 of 2007, there are four competencies of teachers' academic qualifications through teacher education; pedagogical, personal, professional, and social competencies. Those competencies are aimed to actualize the need in improving the quality of education in widely scope

The nature of teachers' pedagogical knowledge and how new knowledge is incorporated into the profession is an especially relevant issue for policy makers. The learning environments of today's classrooms are becoming more diverse and teachers are expected to teach " $21 \mathrm{st}$ century skills" that are the new priority among OECD countries and partner economies. In our 
increasingly complex, knowledge-based and interconnected digital societies, the labour market requires a new set of skills previously of little significance for seeking employment. Today, skills such as creativity, critical thinking, problem-solving, collaboration, communication, among others, are necessary to succeed in the labour market. These new demands require teachers to deviate from traditional teaching methods and to employ innovative, evidence-based teaching practices. For some countries, this might entail a re-skilling of the current teaching workforce and upgrading of the profession's knowledge base within teacher education institutions and through professional communities. Therefore, understanding what the current knowledge base looks like will help determine whether and to what extent re-skilling is required [1].

Science is a way of asking and answering questions about the physical aspects of the universe. Science is not just a collection of facts or a collection of answers to questions, but rather a process of continuing dialogue with the surrounding physical environment. Saintis with special expertise, generally have language, methods and habits of mind to construct explanations of nature. This knowledge is sometimes separate and even contrary to the usual way of finding out. Science has a role to make choices. Scientific knowledge as a discipline knowledge, constructed identically and symbolically in nature. Scientific reasoning is characterized by explicit theoretical formulations that can be communicated and tested by supporting evidence [4].

Science learning is independent of the science itself, that science is regarded as a body of knowledge, a way of thinking, a way of thinking, and a way of investigating (science as a means of inquiry). This shows that science learning involves the use of a number of senses, hands-on and tools or manipulative minds-on. That is, in the process of learning science there is a form of interaction both in thinking and working. Chiappetta \& Kobala (2010) [5].

To measure the achievement of elementary science students' competence using the National Standard School Exam. The National Examinations held at Elementary School are the activities of measuring and evaluating the students' competence to gain recognition of learning achievement, in this case the achievement of science learning. [6] The changes in science and educational system have also affected teachers' competencies. There is strong relationship among the other sciences and system of society and they affect educational system and teachers' competencies. Educational system can be based on scientific results of educational sciences, psychology, economy, technology, sociology and so on.

The results of the study Wardoyo (2015) found that pedagogic competence had a significant effect on teacher performance. The better the teacher's pedagogic competency is accompanied by improved performance, and vice versa[7]. In the research literature on teaching and teacher education, there is a shared understanding that teachers' professional knowledge is an important determinant of instructional quality that impacts students' achievement gains (Baumert \& Kunter, 2006; Bromme, 1997; Munby, Russell, \& Martin, 2001) [8]. Yet few empirical studies have assessed the different components of teachers' knowledge directly and separately to predict instructional quality or student outcome. The main goal of this study was to explore whether teachers' pedagogical content knowledge as a crucial component of teachers' professional knowledge makes a contribution to explaining differences in students' learning outcomes in elementary science education.

Based on the backdrop above then the purpose of this study find out descriptively the pedagogic competence of sixth grade teachers in elementary school and aims to determine the relationship of teacher pedagogic competence to the national science exam results in elementary schools in the district Gerokgak. 


\section{Research method}

Research method used is ex post facto correlation research. Ex post facto that research in which the independent variable orvariables have already occurred and in which theresearcher starts with the observation of a dependentvariable or variables.He then studies the inde-pendent variables in retrospect for their possiblerelations to, and effects on, the dependent variableor variables (Kerlinger, 1964) [9].The sample was taken by 29 sixth grade teachers from 45 elementary schools located in sub district gerokgak district Buleleng Bali. Random sampling with eastern, middle and western divisions and samples are all civil servant teachers with an average of 10 years teaching experience

Pedagogical competence was taken using a questionnaire with 30 questions with three choices of answers that are often, occasionally and never, consisting of ten dimensions : (1) controls the characteristics of leas from the physical aspect, the spiritual moral, social, cultural, emotional and intellectual; (2 ) control of learning theories and principles of learning that educates ; (3) develop curriculum related to the subject matter; (4) conducting educational learning ; (5) utilize information and communication technology for the sake of learning; (6) facilitate the development of potential learners to actualize their potential; (7) communicate effectively, empathetic, and manner with the students; (8) conducting the assessment and evaluation processes and learning outcomes ; (9) utilize the assessment and evaluation for the sake of learning ; (10) take action to improve the quality of reflective learning.. While student exam data is taken from data of science exam result 2017 issued by Buleleng District Education Office.

Descriptive data analysis of teachers' pedagogic competence and national exam results were analyzed by calculating the mean. Furthermore, to determine the high or low quality of research variables, the mean scores for each variable are converted using the Mean Ideal and deviation Ideal criteria. While to analyze the relationship of pedagogic competence with national exam result in this research uses correlation Spearman's rho technique with the help of SPSS 16.

\section{Results and Discussion}

Pedagogic competence is one of four competencies that must be possessed by professional teachers. Maclellan (2008) 10] discusses pedagogical competence using the term "pedagogical literacy" and argues that it is essential that teachers develop both their knowledge and skills in order to be able to adapt to different situations, and that writing and documentation is a suitable method to support their professional development.

Table 1. Summary Table on the Level of Pedagogic Competence of Elementary Teachers and National exam Result

\begin{tabular}{|c|c|c|}
\hline Variable & Mean & Interpretation \\
\hline Pedagogic competency & 77,970 & Very high \\
\hline National exam result & 74,855 & Very high \\
\hline
\end{tabular}

Based on the analysis of competency data of elementary school teachers in Gerokgak subdistrict, it was found that 77,97 teachers were competent with very high category. Teacher pedagogical content knowledge mainly influences student learning whereas teacher motivation mainly influences students'interest [11]. [12] Pedagogical competence is primarily concerned with the level of understanding of learners, instructional design, and implementation of learning the diagnosis, evaluation of learning, the development of learners has provided significant support in the form of professional pedagogical teaching. 
The teacher understands, Competency and Attitude towards the teaching profession directly impacts the student's performance in all spheres. Teacher's beliefs and their Attitude towards the teaching profession affect the behavior of the students. Teacher is an activator of social change. $\mathrm{He} / \mathrm{She}$ are directly linked with the future of the students and today's students are responsible citizens of tomorrow [13].

Table 2 Correlation between pedagogic competence and national exam results

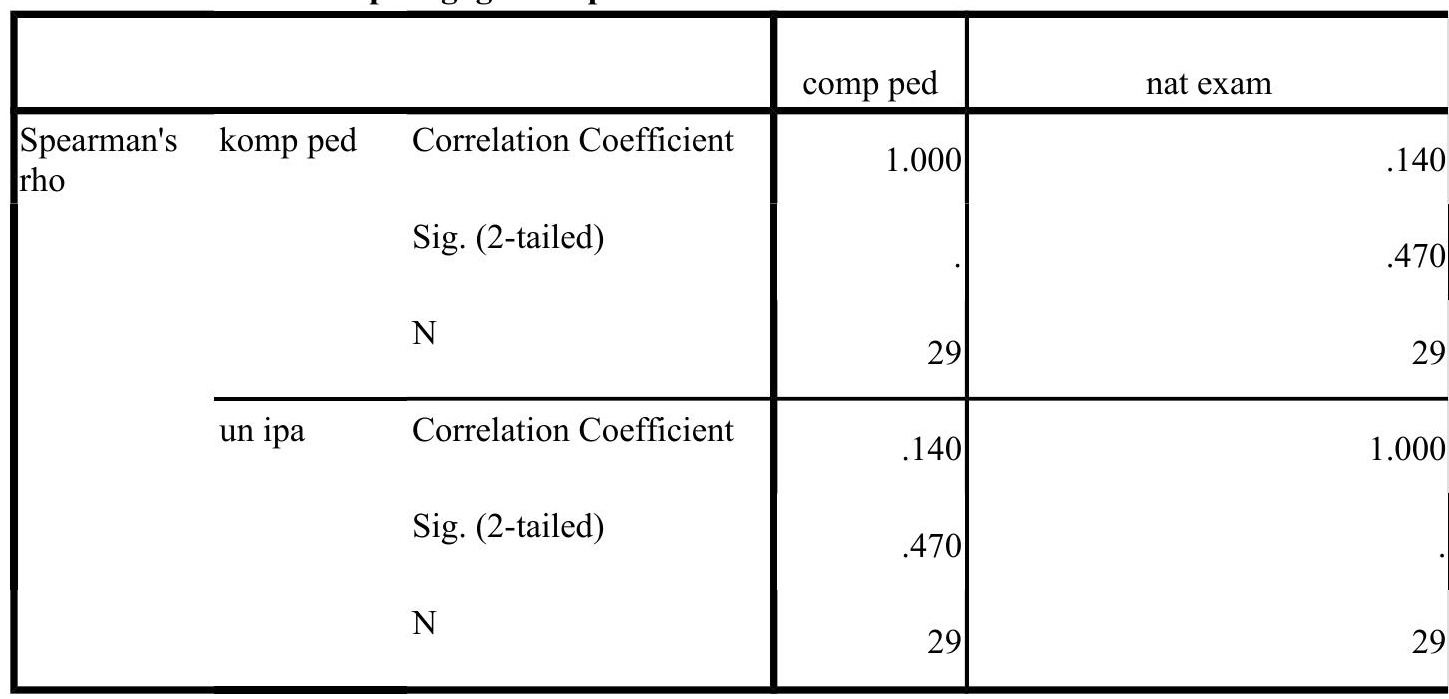

Based on data analysis with the help of SPSS 16, in correlation coefficient rho roughly 0.47 which means having a moderate level of relationship or having a significant relationship. To see the significance of the relationship continued with the significance test with $\mathrm{t}$ test. Based on $\mathrm{t}$ test results in $t$ count can be 2.765 and $t$ table at $5 \%$ significance level of 2.052 . Meaning there is a significant relationship because $t$ count greater than $t$ table $(2.765>2.052)$. To see how much influence pedagogic competence of science exam results, followed by calculating the coefficient of determination. The calculation of coefficient of determination is $0.2209(22.09 \%)$ That is, teachers' pedagogic competence gives $22.09 \%$ influence to the science exam results and $78.91 \%$ is influenced by other factors not implemented in this study. Pedagogic competence of teachers give influence to the results of national science examinations, it is proved that the results of student learning is influenced by external factors that is pedagogic competence.

[13] It is science education that prepares fusion talent required by modern society and countries that lead the world economy innovatively reform the science education. It has predicted that the country would be a positive and creative brain. The science education in the early childhood education field is either demonstrating the experiment plan and process of experiment or choosing to experience activities follow the instructions of the teacher rather than selecting child's ability and intelligence. Learning effi-ciency is increased when infants recognize the individual and the individual teaching and learning in a suitable way. Real intellectual power is the power that the amount of knowledge, but knowledge can operate properly

In order to ensure meaningful and consistent science learning opportunities at the primary level, primary teachers must be supported to confront their existing ideas about science and science teaching and learning if they are to begin to articulate the problematic nature of the perceptions they use to define their practice. Getting at the ways that teachers think about 
science and science education is critical if we are to understand what matters in a primary school context and why. With support, primary teachers may begin to think differently not only about their role as science teachers but also the type of learning they value for their students and the role they want to see their students play as active, critical thinkers and learners in science. Documenting stories of primary school teachers drawing on aspects of quality teaching and learning in primary schools is useful in showcasing to others what is possible and encouraging that shift in thinking. Providing alternative ways of thinking about science teaching may enable primary teachers to relinquish their personal feelings of inadequacy, build on their existing pedagogical strengths and provide a consistent science learning experience for all primary students. In this way primary teachers may come to see new possibilities and opportunities for science learning as well as realizing the potential science learning which exists in the experiences that they presently provide for their students [14].

\section{Conclusion}

Science education need to implement innovative classroom activities, such as research activities and real problem solving, which enables students to mobilize and integrate different competences in order to construct explanations and/or coherent arguments, related with everyday life socio-scientific issues. For that teacher must have a good pedagogic competence in science learning. Pedagogical competence is primarily concerned with the level of understanding of learners, instructional design, and implementation of learning the diagnosis, evaluation of learning, the development of learners has provided significant support in the form of professional pedagogical teaching. In addition to the role of teachers there are several factors that affect the learning outcomes of science include: motivation, interest, early knowledge of students about science, environment and parents factor.

\section{Acknowledgement}

A thank you to Prof. Dr. I Wayan Suastra. M.Pd as the Director of Graduate University of Education Ganesha Singaraja which gives a lot of encouragement so that this research can be completed. Do not forget to the friends of Undiksha basic education doctoral program which gives many suggestions related to this research.

\section{References}

1. S. Guerriero. (ed.) Pedagogical Knowledge and the Changing Nature of the Teaching Profession, OECD Publishing, Paris. http://dx.doi.org/10.1787/9789264270695-en. (2017)

2. D. Sulisworo, R. Nasir, I. Maryani. Identification of teachers' problems in Indonesia on facing global community. https://www.researchgate.net. (2016)

3. S. Aimah, M. Ifadah, D.A. Bharati, D. A. Building Teacher's Pedagogical Competence and Teaching Improvement through Lesson Study. Arab World English Journal, DOI: https://dx.doi.org/10.24093/awej/vol8no1.6

4. N. Y. Rustaman. Education and Science in Developing High Level Thinking Skill for Character Development. Proceedings of a national biology seminar. Vol 8. No 1. http://jurnal.fkip.uns.ac.id. (2011). 
5. Rahmawati. Integration of Culture Value Siri Pese / Pacce of Bugis-Makassar Society in Science Lesson. www.fkip.unismuh.ac.id. (2015)

6. K. Selvi. Theacers' Competencies. https:www.researchgate.net/publication/. (2010)

7. C. Wardoyo. The Measurement of Teacher's Personality Competence and Performance Using Embedded Model. files.eric.ed.gov/fulltext/EJ1077384.pdf (2015).

8. K. Lange, T. Kleickmann. K. Möller. Elementary Teachers' Pedagogical Content Knowledge and Student Achievement in Science Education. https://www.uni-muenster.de. (2012).

9. L. Harold G. Ex Post Facto Studies as a Research Method. Special Report. https://eric.ed.gov/?id=ED090962. (1973)

10. J. From. Pedagogical Digital Competence - Between Values, Knowledge and Skills. https://www.researchgate.net. (2017)

11. M.M. Keller, K. Neumann, H.E. Fischer. The Impact of PhysicsTeachers' Pedagogical Content Knowledge and Motivation on Students' Achievement and Interest. http://onlinelibrary.wiley.com/doi/10.1002/tea.21378/full. (2016).

12. A. Hakim. Contribution of Competence Teacher (Pedagogical, Personality, Professional Competence and Social) On the Performance of Learning. www.theijes.com/papers/v4i2/Version-3/A42301012.pdf. (2016).

13. A. Shokeen. Relationship among Pedagogical Understanding, Teaching Competencies and Attitude towards the Teaching Profession of B.Ed. Student Teachers: An Exploratory Study. http://www.confabjournals.com. (2016)

14. E.G. Yun, S.H. Park. The Research of Early Child Scientific Activity according to the Strength Intelligence. http://onlinepresent.org/proceedings/vol131_2016/32.pdf. (2016)

15. Fitzgerald, A., \& Smith, K. Science that Matters: Exploring Science Learning and Teaching in Primary Schools. Australian Journal of Teacher Education, 41(4). http://dx.doi.org/10.14221/ajte.2016v41n4.4. (2016). 